\title{
Suitability of Coursebook Materials for Teaching English Through CLIL
}

\author{
Melita Lemut Bajec \\ Secondary School Veno Pilon Ajdovščina \\ melita.lemutbajec@gmail.com
}

\begin{abstract}
CLIL is a didactic approach that assumes simultaneous learning of a foreign language and another subject and enables the fulfilment of goals that each individual subject can never reach on its own. Despite much research that speaks in favour of the approach it is still relatively unknown in Slovenia and therefore received with much scepticism. Teachers are worried about their (in)competence of knowing two fields of expertise on a high enough level as well as about the demands for interdisciplinary team teaching as both call for changes on organizational and content-related levels and presuppose creating unique authentic materials that would take into account many contextual factors. The purpose of the research was a critical analysis of three coursebooks currently widely used in upper-secondary education. Particular emphasis was put on the suitability of the selected coursebooks for team teaching of Biology and English through CLIL. The research focused on levels of cognitive demand, authenticity, comprehensiveness, and motivation arising from the three selected coursebooks. The analysis revealed that the coursebook materials are very simplified, thus not offering many cognitive challenges and that students wish for problem-based lessons as they are aware of the importance of skills such as the ability to form arguments, evaluate, analyse and make autonomous decisions. In order to develop these skills, and thus raise critical thinkers, language and subject teachers must unite, which presupposes a different kind of work ethics as well as a different mind-set. CLIL proves to be a very successful tool in achieving this.
\end{abstract}

Keywords: CLIL, coursebooks, upper-secondary education, critical thinker

\section{Introduction}

CLIL (Content and Language Integrated Learning) is a didactic approach that has been present in Europe since the 1990s. It postulates that a subject is taught through a foreign language, which means simultaneously meeting the goals of individual school subjects as well as joint objectives that overcome specific subject fields. Despite extensive research done on its benefits and strong recommendations from EU institutions that encourage multilingualism, many Slovenian academics as well as laymen express deep reservations about this innovative didactic approach. The first reason for such an at- 
titude is the safeguarding of the Slovenian language, and the second the feeling of incompetence that comes with the requirements for interdisciplinary team teaching. Quality CLIL lessons require changes in the arrangement of the timetable and the ways content is presented as well as challenge teachers to produce their own materials.

Therefore, the aim of the research was a critical analysis of 3 coursebooks currently most widely used in upper-secondary education (grammar schools) with focus on suitability of the materials for interdisciplinary team teaching of English and Biology through CLIL rationale. Levels of cognitive demand, authenticity, motivation, and comprehensiveness as arising from coursebook materials were closely examined. The participants of the research were Biology and English teachers as well as 1st, 2nd and 3rd grade students of the grammar school programme. Qualitative and quantitative data helped us determine that the analysed materials lack sufficient cognitive challenges because they are oversimplified; that students wish for problem-based lessons because they are aware that only knowledgeable individuals capable of independently assessing, evaluating, forming argumentative opinions and making decisions can succeed in the world they are about to enter. The path to the lessons that will equip students with the above-mentioned skills is certainly in close collaboration between a language teacher and a subject matter teacher. This assumes a different kind of work as well as a different mindset.

\section{Theoretical Part}

\section{CLIL (Content and Language Integrated Learning)}

In 2002, the European Council of Barcelona invited European Union countries to take action and encourage development of basic skills including learning of two foreign languages from the youngest age. As many countries, including Slovenia, followed this initiative, today $90 \%$ of the pupils in mainstream education of $15 \mathrm{EU}$ countries learn two or more foreign languages (Eurydice $2017,12)$. CLIL is, therefore, grounded as a very successful teaching approach on all levels of education as it increases students' foreign language competences, encourages intercultural understanding and is a very important step towards a multilingual Europe (Jazbec and Lovrin 2015, 76). It is a didactic approach that assumes additional subject matter learning through a foreign language within the same curriculum frame but not on account of other subject lessons (Eurydice 2017, 14). CLIL is oftentimes understood as a language bath, integrated learning, bilingual lessons etc., which may mark the same or a very similar approach, yet it is more neutral and therefore applicable to 
many social contexts as well as relevant for many different European educational policies (Lipavic Oštir and Jazbec 2009, 104-5).

CLIL requires applying a critical perspective when teaching and learning a language (Lipavic Oštir, Lipovec, and Rajšp 2015, 13). Lessons are given different foci as the main attention is paid to the adoption of a pragmatically cultural competence, a foreign language competence and a non-language subject competence (Balek and Jazbec 2010, 27). As CLIL's main rationale is on studying through understanding and comprehending, teachers that follow CLIL meet this pivotal goal more spontaneously and also more intensively than teachers that follow traditional ways of teaching language or nonlanguage subjects (Lipavic Oštir and Jazbec 2009, 110). Such studying also ensures better understanding of the content and the connections in between (Lipavic Oštir, Lipovec, and Rajšp 2015, 13). Students as active co-creators and lesson builders have a chance to experience a foreign language in all its variety and diversity (Retelj and Pižorn 2010, 140).

CLIL is flexible at its core and enables different models and realizations, depending on what a specific model sets in the intersection, be it content, language and communication, culture or cognition (Pevec Semec 2015, 46). Regardless of the emphasis that each individual model places, the starting point should always be non-language subject syllabi so as to avoid putting an additional burden on students. We should focus on extending their knowledge of the topics they are already acquainted with (Retelj and Pižorn 2010, $140)$, yet at the same time we need to be very careful that the content is cognitively challenging and initiates critical thinking (Pevec Semec 2015, 56). Problem-based lessons arising from CLIL rationale develop communication skills and strengthen profession-related literacy as well as boost students' self-confidence. In particular, CLIL can be very motivational in vocational schools as students see it as a simulation of their possible future professionrelated situations (Lipavic Oštir 2009, 51). To sum up, CLIL's value is beneficial at all levels and in all programmes.

\section{Challenges for Teachers and Students}

Teaching CLIL sets high expectations and demands on both parties - students and teachers. Students get to know advanced content of one specific subject, by being simultaneously challenged with the demands and principles of a foreign language (Retelj and Pižorn 2010, 137). On the other hand, foreign language teachers need to be knowledgeable in many different subject fields, whereas subject teachers need to master a foreign language. That is also the reason why CLIL teachers in $15 \mathrm{EU}$ school systems are required to 
demonstrate additional foreign language knowledge on $B_{2}$ or $C_{1}$ level (Eurydice 2017, 15).

Furthermore, through acquiring adequate didactic and methodological knowledge teachers need to develop their own cognitive (learning to learn), affective (learning to be) and pragmatic dimension (learning to do), which that forces them to step out of their comfort zone and enter a less predictable zone of progressive teaching that is characteristic of the environments in which a target language has the second or even the first language position (Skela and Sešek 2012, 74).

As a student is at the focal point of our attention, the teacher seems to fade into the background, $s /$ he is no longer a sole transmitter of knowledge, the only source of information and a mistake hunter, but rather a mentor, animator and co-creator of an optimal learning environment (Skela 2008, 182). So prepared and conducted lessons speak in favour of students' development and success (Brumen, Ivanjšič Kolbl, and Pšunder 2015; Retelj 2015). Students are no longer passive in-takers of information but active participants in the learning process and take on responsibility for their own knowledge; they have to study independently and make use of their mental effort by giving a sensible interpretation to the data through acquiring problem-solving as the primary study technique (Skela 2008, 159).

In addition, with CLIL it is the way to the goal that is important; to see how knowledge gets created and which thinking processes are going on. Lah Šuster (2013, 98-99) points to the fact that knowledge is built gradually, upon acquiring first declarative (getting to know the facts, data, information, rules and theory), then procedural (how to do something) and strategic knowledge (when and why to do something). The final stage is metacognitive and helps students actively control, assess and improve their own reasoning and its use (Pevec Semec 2015, 54).

Besides this, educators must be aware that older students function on a different cognitive level than younger ones, and it is the explicit learning and metacognitive knowledge that counts for them (Lipavic Oštir and Jazbec $2009,112)$. Also, older students know that a foreign language is meaningful for their own personal and professional career to a much greater extent, which inherently changes the position of a foreign language within the school context (p. 113). As foreign languages have the ability to bond different school subjects, they necessitate introduction of an integrative curriculum, interdisciplinary lessons, team teaching, and timetable adjustments as well as joint planning, assessment and evaluation of the students' progress (Retelj and Pižorn 2010, 136). 


\section{Learning Foreign Languages and CLIL in Slovenia}

Learning and teaching foreign languages in Slovenia is rather distinct due to its specific historical context. It has to be regarded as an evolution, intertwinement and synthesis of the most important historic and global trends, endeavours and attempts (Skela and Sešek 2012, 63).

To start with, the attitude towards foreign languages in Slovenia is ambivalent. On the one hand, mastering foreign languages was a must for our predecessors if they wanted to ascend the social ladder, and that is why foreign language skills have always been a prestige. This also explains the fact why today so many children learn foreign languages in a formal or non-formal way from kindergarten and primary school on (Lipavic Oštir and Jazbec 2009, 113).

On the other hand, there are considerable worries about the demise of our mother tongue, in particular among experts of the Slovenian language (Lipavic Oštir and Jazbec 2009, 107), plus an assumption that multilingualism is a burden for an individual's progress (Lipavic Oštir 2009, 42). Consequently, it does not come as a surprise that despite EU recommendations CLIL enters the Slovenian learning environment very slowly, non-systematically and with much resistance (Pevec Semec 2015, 55).

Another unsettling requirement of CLIL is full collaboration between school subjects and teachers, in particular with teachers of the Slovenian language (in our case) (Pižorn 2010, 140). If we want to achieve more advanced learning objectives such as critical thinking and problem solving we need to apply a multi-perspective approach (Pavlič Škerjanc 2010, 30).

CLIL shakes and interferes with the well-established traditions of teaching, as it emphasizes constructivism, experimental work, independent and collaborative models of working, and implies very practical and useful aspects of studying a foreign language (Jazbec and Lovrin 2015, 76). The above stated should convince critics in the Slovenian learning environment that their doubts, concerns and second thoughts on CLIL are pointless and therefore give CLIL a chance to prove its true value.

\section{Coursebooks}

Quality lessons are closely related to the choice of quality educational resources. Therefore, it is worth examining them. Despite the availability of other contemporary forms of online educational resources, softcover coursebooks remain an important source and a significant factor of a foreign language learning process (Balek and Jazbec 2010, 30). Skela $(2008,155)$ emphasizes the meaning that coursebooks have - they reflect scientific achieve- 
ments as well as a certain philosophical orientation and as such contribute to and inspire societal changes. Therefore, it is of paramount importance for any teacher to be well acquainted with coursebooks if they want to make the most effective use of their resources as well as adjust them to their students' needs (Skela 2008, 91).

Also, research reveals that coursebook materials are oversimplified and already familiar in content to the students. When emphasizing language (vocabulary, grammar), the content gets neglected, and is consequently randomly problematized (Banegas 2013, 347). CLIL, however, is not about restudying the already known topic in another language (Coyle, Hood, and Marsh 2010, 96), it is about getting to know the topics in-depth, expanding new horizons and teaching critical distance towards the content.

Further on, successful foreign language acquisition requires overlapping of a foreign language and non-language curricula, which in the Slovenian study environment is not a frequent occurrence. One of the reasons for that is also in 'mainstream' coursebooks as they are not built upon CLIL rationale, which - to coursebooks' defence - is extremely difficult to incorporate due to many contextual factors (such as students' age and cognitive development, levels of foreign language knowledge, curriculum and educational policies). Therefore, for economic reasons publishing houses do not decide to prepare and publish CLIL-based coursebooks on an international range (Lucietto 2009, 13). For that reason, creation of CLIL materials and attempts for the overlapping of the curricula objectives are mainly in the domain of individual teachers.

\section{Empirical Part}

\section{Definition of the Research Problem and of the Purpose of the Survey}

As the topics in the English language coursebooks are oversimplified, descriptively and shallowly prepared, they do not pose major cognitive challenges, which negatively affects, in particular, the more-able students; they get bored, demotivated and disinterested. Consequently, they see no point in participating in the lessons, and show little or no interest for further selfinvestigation into the subject matter. Secondly, the materials in the analysed coursebooks are not suitable for quality interdisciplinary team teaching based on CLIL rationale but present merely a solid foundation on which to form one's own materials. Also, the existing materials neither stimulate problem-solving nor require higher thinking processes. As a result, such lessons do not raise critical thinkers.

The purpose of this research is, therefore, to analyse Biology-related topics in three English language coursebooks and find out which of the topics could 
be a good foundation for further interdisciplinary team teaching via CLIL. Also, we want to find out if there are any discrepancies between students' and teachers' assessment related to levels of cognitive demand, authenticity, motivation, and comprehensiveness that coursebook materials provide. We also want to find out if there are any statistically significant differences between the group of higher- and lower-graded students in the English language subject when experiencing coursebook materials.

\section{Research Questions and Hypotheses}

The following research questions and hypotheses were set:

Q1 Which and how many topics in the selected English coursebooks are suitable for interdisciplinary team teaching of English and Biology via CLIL?

Q2 To what extent are the selected topics suitable as well as already prepared for hands-on interdisciplinary team teaching of English and Biology via CLIL?

Q3 Which cognitive processes are anticipated alongside learning the subject matter in English coursebooks and to what extent do they raise a critical thinker?

Q4 To what extent do the contents and objectives of specific English topics match the objectives of Biology?

Q5 To what extent does the students' assessment differ from the teachers' assessment when looking into levels of cognitive demand, authenticity, motivation, and comprehensiveness that English coursebooks provide?

$\mathrm{H}_{1}$ There are statistically significant differences between higher- and lowergraded students when referring to levels of cognitive demand that coursebook materials provide.

$\mathrm{H}_{2}$ There are statistically significant differences between higher- and lowergraded students when referring to levels of comprehensiveness that coursebook materials provide.

$\mathrm{H}_{3}$ There are no statistically significant differences between higher- and lower-graded students when referring to levels of authenticity that coursebook materials provide.

$\mathrm{H}_{4}$ Coursebook materials motivate higher-and lower-graded students to the same extent.

\section{Methodology}

The paper presents a qualitative research with elements of empirical quantitative research based on descriptive and causal research methods. 
Table 1 Constructs According to Internal Consistency and Mean Value

\begin{tabular}{|c|c|c|c|}
\hline Construct & (1) & (2) & Statements comprising the constructs \\
\hline $\begin{array}{l}\text { Level of cogni- } \\
\text { tive demand }\end{array}$ & 0.723 & 3.03 & $\begin{array}{l}\text { I think the topics in the coursebook are oversimplified. } \\
\text { I think the topics in the coursebook are easy. } \\
\text { I think the topics in the coursebook are demanding. }\end{array}$ \\
\hline Authenticity & 0.742 & 3.46 & $\begin{array}{l}\text { I think the topics in the coursebook are realistic. } \\
\text { I think the topics in the coursebook are practical. } \\
\text { I think the topics in the coursebook are factual. } \\
\text { I think the topics in the coursebook are related to life. }\end{array}$ \\
\hline Motivation & 0.691 & 3.17 & $\begin{array}{l}\text { Topics in the coursebook are appealing. } \\
\text { Topics in the coursebook are interesting. } \\
\text { Topics in the coursebook are boring. } \\
\text { Topics in the coursebook inspire me to do further research. }\end{array}$ \\
\hline $\begin{array}{l}\text { Comprehen- } \\
\text { siveness }\end{array}$ & 0.663 & 3.31 & $\begin{array}{l}\text { I think the topics in the coursebook are presented from } \\
\text { all perspectives. } \\
\text { I think the topics in the coursebook are holistically presented. } \\
\text { I think the topics in the coursebook are expertly presented. } \\
\text { I think that the topics in the coursebook are critically } \\
\text { presented. }\end{array}$ \\
\hline
\end{tabular}

Notes Column headings are as follows: (1) Cronbach $\alpha$, (2) mean value.

After fulfilling the criteria (the coursebooks need to be currently confirmed by the Slovenian Ministry of Education, and they also need to rank among the three most widely-used ones in Slovenian upper-school education - grammar schools) three coursebooks were selected for a further detailed analysis.

Further on, on the basis of a semi-structured interview with a Biology teacher, an assessment of suitability of the materials for interdisciplinary team teaching of Biology and English via CLIL was prepared. Prior to the meeting the teacher had been asked to bring her own Yearly Syllabus Plan for Biology, National Curriculum Plan for Biology and Matura Exam Catalogue for Biology. This way we gathered information on possible topics for interdisciplinary lessons as well as joint objectives that CLIL would meet. Special attention was also paid to the objectives and cognitive processes that are realized through specific topics.

Next, five English language teachers were asked to fill out an Assessment form, consisting of nine open-ended questions that referred to their perception of levels of authenticity, cognitive demand, motivation, and comprehensiveness that arise from the analyzed coursebook materials.

Finally, we were also interested how participants ( 87 first, second and third year grammar school students aged 15-18 of a smaller upper-secondary grammar school in the Primorska region) regard the topics in the analysed 
coursebooks. Data were obtained with an online questionnaire that consisted of a 5-point Likert type scale and two open-ended questions. Quantitative data had to do with four constructs: levels of cognitive demand, authenticity, motivation and comprehensiveness. Besides that, we also attained qualitative data on participants' standpoint on potential English lessons that would follow CLIL rationale and stress problem-solving skills.

Processing of the on-line data included bivariate statistical analysis on a descriptive and inferential level. Individual variables (statements) were joined into four constructs and were incorporated in the analyses in the form of mean variables (table 1). The given values, representing an individual's level of agreement varied from 1 (meaning 'do not agree at all') to 5 (absolutely agree), enabled comparison and interpretation. Processing of the questionnaire data started by measuring Cronbach's alpha, a measure of internal consistency, which proved to be acceptable $(\alpha>0.6)$ or good $(\alpha>0.7)$. Upon that we ran a $t$-test in order to see individual constructs. Before that, we had run Levene's test to assess the equality of variances that tests the null hypothesis that the population variances are equal.

\section{Results and Discussion}

The following section will first deal with the characteristics of the analysed coursebooks and cognitive processes anticipated alongside studying the subject matter. Further on, we will propose Biology-related topics that present a suitable foundation for conducting Biology-related topics in English lessons via CLIL. Next, we will identify joint objectives that such lessons would meet. Also, teachers' and students' responses on coursebook materials when related to cognitive demand, motivation, comprehensiveness, and authenticity of the coursebook materials will be discussed. We will also review participants' responses related to problem-based teaching/learning through CLIL rationale. This way we will answer our research questions and hypotheses on which this research paper builds.

\section{Characteristics of the Analysed Coursebooks}

It needs to be stressed that the three analysed coursebooks - On Screen B2 and $\mathrm{B}_{2}+$, New Success Intermediate and Upper-Intermediate as well as New Headway Intermediate and Upper-Intermediate - effectively achieve the objectives of the English language as a school subject, which is knowledge of English on $\mathrm{B}_{2}$ and $\mathrm{B}_{2}+$ level. They follow a communicative approach and emphasize communicative functions of the language. They highlight vocabulary (synonyms, antonyms, word formation, idioms and set phrases), and 
there is also a section on acquiring new and practising already familiar grammar plus studying pieces of writing necessary for Matura.

Each unit presents the topic gradually, taking into account a 'linguistic loop', which is a very important didactic tool when acquiring a foreign language. It helps one learn receptive and productive skills and is an essential part of a linear advancement in bettering linguistic skills (Lipavic Oštir, Lipovec, and Rajšp 2015, 16).

Also, it is transparent that the units follow the same structure and pattern (text, vocabulary tasks, communication activities, writing assignments, listening comprehension activity) and thereby present a safe and expected learning environment, which is very important for weak students to whom language learning poses a challenge.

\section{Topics Suitable for Preparing Biology-Related English Lessons via CLIL}

Upon a critical analysis of the three English coursebooks we found four concurrent topics in all three coursebooks, e.g. Sports and Fitness, Food, The Environment and Environmental Problems, Health \& Injuries and IIInesses, which could present a good foundation for interdisciplinary team teaching of English and Biology via CLIL, provided extra study material is prepared. Despite different presentations of the topics they all cover meaningful vocabulary needed for everyday communication related to the subject matter.

\section{Cognitive Processes Anticipated alongside Learning the Subject Matter}

The above-mentioned topics are familiar to students as they were studied in primary school through Science (Biology, Physics, Chemistry, Natural Sciences) as well as English. In upper-secondary school students mostly expand their vocabulary, revise and add to the already-known facts and solutions, yet they do not deepen the understanding of the concepts, they do not problematize them, and they do not look for alternative/innovative solutions.

Moreover, the texts are from the Matura's point of view insufficiently demanding. Teacher Š. warns: 'On Matura students are expected to deal with much more difficult texts. Also, types of tasks in coursebooks only partially coincide with Matura tasks.' Further on, the analysis shows that the topics are presented in a very descriptive way, which means that critical thinking is not at the core of the materials. 'Each unit consists of two or maximum three open activities where critical thinking can occur which is far too little to carry out problem-based lessons,' says a beginner teacher. Even tasks that partially encourage critical thinking are formed in a way that offer solutions and lead to very expected outcomes. 
Activities that require original and creative thinking, searching for alternative solutions as well as situations/problems that would enable greater identification of the students with the topics have to be prepared by the teachers themselves, as 'coursebooks offer just a starting point with the basic vocabulary,' says teacher T. Therefore, it can be assumed that students might be robbed of cognitive challenges if confronted only with coursebook materials. Our assessment is in line with the Argentinian researcher Banegas (2013, 352) who claims that topics are presented as if targeted to primary school pupils.

One of the reasons why the materials are simplified is their adjustment for foreign language learning. 'Texts, despite their contemporary nature, feel rigid, artificial and in a way forced,' says the participating male English teacher. Listening comprehensions and models of writing pieces tend to be even more simplistic than reading comprehension texts. So much so that models of writing assignments can serve only as a prototype to be referred to in the future when confronted with a more complex assignment.

Following the above analysis, it becomes clear that most of the tasks require lower-order thinking processes (knowledge, understanding, application), whereas tasks that require higher-order thinking processes (synthesis, analysis, evaluation) are present on a minor scale and refer mainly to communication (opinion forming) or teaching the students how to write Maturarequired pieces of writing (formal letter, report, article, essay). Yet, it should be justly questioned if and to what extent students make use of their innovative, original and authentic ideas and solutions when writing the required pieces if all that students do is make use of already-known arguments, which they were led to by the coursebook. Teacher Š. also observes that students tend to concentrate more on form than on the content itself. Following the prescribed form, they neglect creative, innovative and original solutions; no wonder that the content remains cliché-like.

To round up, the analysis also showed that students are only rarely given a chance to carry out independent research work. This is not necessarily part of the unit; therefore, it is written below the line (e.g. in On Screen) or at the end of the unit (as it is in New Success) and meant as homework. The teacher can - if/when lacking time - decide to skip these assignments.

\section{Challenges for the Teachers Wanting to Carry out Lessons Built on CLIL Rationale}

As already pointed out, topics in the three coursebooks present a solid foundation on which teachers can work and prepare their autonomous materials 
that will meet the objectives of both subjects. According to one of the participating teachers, 'Many of the topics could be worked further on in collaboration with other subjects and consequently offer a palette of topics and expand students' horizons and knowledge. That way also students that struggle with the language might find it more relevant; or if the language is too easy for some, they could expand their knowledge in the field they are not so confident in.'

Also, as it is really difficult (at least in Slovenia) to find a teacher that is a subject-matter and a foreign language expert, the most effective CLIL can be achieved through interdisciplinary team teaching. This, however, sets high expectations on teachers who worry about 'extra workload that would come from studying the topic in order to prepare quality lessons of this type' (teacher M.). Further on, all participating teachers see many obstacles in 'fast-paced scientific advancements that require constant education in many different fields of expertise.' Nonetheless, teacher I. who participated in pilot-run European programmes (aimed at introducing interdisciplinary team teaching into a regular teaching practice) added: 'The project connected teachers of different profiles. It took a lot of time and self-discipline. The biggest challenge was finding time to work together in the classroom. However, as a teacher I benefitted tremendously.'

\section{Possible Interdisciplinary Links and Joint Objectives}

The main objective of English lessons is the development of holistic competences for intercultural and interlinguistic understanding (Ministrstvo za šolstvo in šport 2008, 7); the main objective of Biology is a holistic understanding of Biology, that is, understanding the concepts and links in between them (Vilhar 2008, 55). Seeing what both National Curricula strive for, it is crucial that Biology and English teachers alike comprehend the necessity of interdisciplinary team teaching as it predisposes work on higher taxonomic levels where understanding of how one field is related to other fields of expertise is prioritized (Vilhar 2008, 80). Such lessons help develop key competences for life-long learning that include creativity, problem-solving, risk assessment, decision making, and critical thinking (Ministrstvo za šolstvo in šport 2008, 8).

Upon a critical analysis of the selected English coursebooks, Yearly Syllabus Plan for Biology, National Curriculum Plan for Biology and Matura Exam Catalogue for Biology, authors of the research identify possible links for interdisciplinary team teaching as presented in table 2 .

We also believe the following would be the joint objectives that such lessons if conducted would meet: 
Table 2 Possible Links for Interdisciplinary Team Teaching

\begin{tabular}{lll}
\hline English & Possible links for interdisciplinary & Biology \\
& team teaching & \\
\hline Pollution and & Tragedy of the commons & Ecology \\
environmental & Endangered species & \\
problems & Sustainable development & \\
& Alternative sources & \\
& Development of life on Earth & \\
& Climate changes & \\
& Endemic and non-indigenous species & \\
& Slovenia as a place of biotic diversity & \\
\hline Food & Food pyramid & Foundations of healthy life \\
& Food labelling & \\
& GMO & \\
& Genetic inheritance & \\
& Food additives & \\
& Modern diseases & Foundations of healthy life \\
& Doping & \\
\hline Sport & Addictions (smoking, alcoholism, drugs) & \\
\hline Injuries, illnesses, & Vaccination & Foundations of healthy life \\
health & Hygiene and infectious diseases & \\
& Mental and physical diseases &
\end{tabular}

- First, students would acquire foreign language terminology of a specific subject matter;

- Secondly, by making use of the right sources and information, they would deepen their understanding of the concepts;

- Finally, as such lessons enhance students' critical thinking skills they would raise critical thinkers able to form a critical distance to (oftentimes fake) information.

\section{Teachers' and Students' Responses to Coursebook Materials}

The following section will deal with the interpretation of the students' grades given to the constructs cognitive demand, authenticity, comprehensiveness, and motivation. We will also analyse possible correlations and discrepancies between the students' and teachers' assessment to the above-mentioned constructs. Finally, we will take a look into students' and teachers' thoughts and doubts about potential CLIL lessons.

\section{Cognitive Demand}

As already pointed out, teachers' professional assessment shows that coursebook materials are simplified. Also students' evaluation of the construct 'lev- 
Table 3 Students' Responses to 'Levels of Cognitive Demand'

\begin{tabular}{lrrrr}
\hline Students & $M$ & $S D$ & Levene's test (Sig.) & $t$-test (Sig.) \\
\hline Lower & 2.52 & 0.83 & 0.407 & 0.000 \\
Higher & 3.38 & 0.78 & & \\
\hline
\end{tabular}

els of cognitive demand' was 3.0 on the scale from 1 to 5 (table 3). As students' grades reflect teachers' assessment it can be concluded that materials in the coursebooks do not provide significant cognitive challenges and do not push students out of their comfort zone. Further on, we wanted to find out if there are statistically significant differences between the group of higher- and lower-graded students. We found out that lower-graded students evaluate materials in the coursebooks as significantly more demanding $(p=0.000)$ in comparison to higher-graded students.

Therefore, our hypothesis that claims 'There are statistically significant differences between higher- and lower-graded students when referring to levels of cognitive demand that coursebook materials provide' can be confirmed. This outcome is very important for teachers when starting to prepare their own CLIL materials. It means that different cognitive abilities should be taken into account and tasks should be built from simpler to more complex ones. This way, students of all abilities would benefit.

\section{Authenticity}

We have already discussed the adaptation of the materials in the coursebooks for the purpose of foreign language learning, which does not agree with CLIL rationale that presupposes work with authentic materials. This is why we wanted to find out how students perceive coursebook materials as we believe that they use authentic texts themselves for their own interests and purposes regardless of the fact whether they belong to the group of higher- or lower- graded students, and therefore know what authentic means as well as how important it is in seeking the correct information.

The average grade of the construct 'authenticity' was 3.5 (table 4), which shows students' awareness that they learn in a quite artificial and adjusted environment. The result of the Levene's test for the construct 'authenticity' was statistically non-characteristic $(p=0.573)$, which means that the assumption was verified and we could run an adjusted $t$-test. We found out that there are no statistically significant differences when grading authenticity between the two groups $(p=0.188)$ (table 4$)$, therefore, we confirm the hypothesis which claims 'There are no statistically significant differences be- 
Table 4 Students' Responses to 'Authenticity' of the Study Materials

\begin{tabular}{lrrrr}
\hline Students & $M$ & $S D$ & Levene's test (Sig.) & $t$-test (Sig.) \\
\hline Lower & 3.34 & 0.74 & 0.573 & 0.188 \\
Higher & 3.55 & 0.68 & & \\
\hline
\end{tabular}

Table 5 Students' Responses to 'Comprehensiveness' of the Study Materials

\begin{tabular}{lrrrr}
\hline Students & $M$ & $S D$ & Levene's test (Sig.) & $t$-test (Sig.) \\
\hline Lower & 3.05 & 0.59 & 0.846 & 0.002 \\
Higher & 3.50 & 0.60 & & \\
\hline
\end{tabular}

tween higher- and lower-graded students when referring to levels of authenticity that coursebook materials present.'

As authentic materials are 'designed not to transmit declarative knowledge about the target language but rather to provide an experience of the language in use' (Tomlinson and Masuhara 2010, 400), it is clear authentic language teaching should be educators' priority.

\section{Comprehensiveness}

When analysing the coursebooks teacher T. pointed to the fact that 'critical thinking, opinion forming, justification as well as problem-based lessons are up to teacher's creativity and incentive,' by which it becomes obvious that good CLIL lessons call for creation of the teacher's own comprehensive and problem-based materials, which is not the case with the analysed materials.

Students' average grade when referring to the construct 'levels of comprehensiveness' is 3.31 (table 5). The grade undeniably shows that students are well aware of the fact that coursebook materials are not holistic, comprehensive and critically presented and therefore do not develop key competences so necessary in life.

We also carried out a $t$-test and found out that there are statistically significant differences between the two groups $(p=0.02)$ when referring to levels of comprehensiveness (table 5) and hereby confirm the hypothesis which says 'There are statistically significant differences between higher- and lower-graded students when referring to levels of comprehensiveness that coursebook materials provide.'

The construct 'comprehensiveness' is in some extent similar to the construct 'levels of cognitive demand,' therefore, it is not surprising that highergraded students are more aware of the superficial and shallow materials and the consequences that arise from that than lower-graded students. 
Table 6 Comparison of the Groups According to the Construct 'Motivation'

\begin{tabular}{lrrrr}
\hline Students & $M$ & $S D$ & Levene's test (Sig.) & $t$-test (Sig.) \\
\hline Lower & 3.02 & 0.75 & 0.564 & 0.078 \\
Higher & 3.28 & 0.63 & & \\
\hline
\end{tabular}

\section{Motivation}

Coyle, Hood, and Marsh $(2010,140)$ stress that it is essential that students' attitude be constantly included in the evaluation. This is why the authors of the research wanted to check if there is any correlation between levels of motivation and study materials, in particular between higher- and lower-graded students. Therefore, we asked the participants what they think of the materials when considering their ability to motivate the students.

Teacher Š. stresses that coursebooks lack topics that students could identify with, which means that the topics could be potentially boring to them. Teacher T. warns that the texts are too long, therefore, unappealing to the students who are no longer used to reading. Teacher $\mathrm{S}$. simply concludes that the materials do not boost students' motivation, as there is not much they can relate to.

Students graded the construct 'motivation' with 3.2 (table 6), which shows their neutrality towards the topics. The $t$-test showed that there are no statistically significant differences $(p=0.078)$ in motivation between the higherand lower-graded students (table 6). Thereby, we confirm our hypothesis that claims 'Coursebook materials motivate higher- and lower-graded students to the same extent.'

To conclude, when preparing CLIL materials it is necessary to think about ways to get closer to the young in order to encourage their curiosity and boost their motivation as well as contribute to a more effective and affective way of learning, all of which refers to stronger and weaker students alike.

\section{Thoughts and Doubts about Potential Lessons Based on CLIL}

Further on, the students were asked if they would like the topics they normally associate with other subjects (e.g. history, biology, physics) to be discussed in English lessons even if it meant more cognitively challenging lessons (more advanced vocabulary, higher thinking processes). 60 students $(75 \%)$ said yes, 20 students ( $25 \%$ ) said no. Among the reasons in favour of the suggestion are the following:

- 'It's very important for our further professional career (further education, job).' (10 students) 
- 'We would expand our horizons.' (10)

- 'We would have more knowledge.' (9)

- 'We would expand our vocabulary (9), in particular terminology.' (4)

- 'We would be able to link between different school subjects.' (10)

- 'Such lessons would be more interesting, down-to-earth and practical.' (8)

Students that are against such lessons present a minority and say:

- 'I see no point in that.' (3)

- 'Topics are already very difficult.' (7)

- 'Topics are already thoroughly enough presented.' (6)

All teachers expressed their concerns that 'an English teacher is not competent enough in the fields that are not his/her expertise in order to present them well.' They also add that this would mean 'investing a lot of time and energy in one's own education.' Nonetheless, all of them are well aware of the importance of being well acquainted with the subject-related terminology for one's future professional career. However, in most cases they do not point to interdisciplinary team teaching as they see huge obstacles in organizing such lessons as well as the preparation of the materials being too time consuming. Teacher T. concludes that it is much more important that the students 'master general competences and strategies that will help them independently acquire new knowledge in areas of their interest.'

\section{Thoughts and Doubts about Potential Problem-Based Lessons}

When asked if they wanted more problem-based lessons which would naturally arise from CLIL postulates, 38 (55\%) students confirmed and $31(45 \%)$ declined. Students who do not want problem-based lessons think that the lessons they currently follow are already 'too problem-based' and add 'it's fine the way it is.' Some students mention 'the level of difficulty that they can't follow', two students say 'they see no point in that.' However, a majority voted for problem-based lessons, stressing:

- 'We would deal with more contemporary issues and learn problem solving skills.' (8)

- 'Lessons would be more realistic.' (5)

- 'We would develop critical thinking skills.' (4)

- 'We would raise awareness and expand our horizons.' (6)

- 'We would exchange different points of view.' (8) 
- 'We would discuss topics more in depth.' (2)

- 'We would better understand and memorize more.' (3)

- 'Lessons would be more interesting.' (6).

All the teachers agree that there are ways to make the lessons more problem-based. However, they are also unanimous that students above all need to learn the strategies that will help them link different types of knowledge and enable them to see that subjects are not separated but intertwined.

\section{Concluding Findings}

CLIL is a didactic approach, in which the language is used as a tool to achieve goals of different subjects. Such an approach enables an in-depth overview of a topic, stimulates work on higher-order thinking levels and raises critical thinkers. Furthermore, quality CLIL lessons call for changes in the arrangement of the timetable and the ways content is presented as well as challenge teachers to produce their own materials based on the materials found in the coursebooks. Another important factor is the mindset of everyone involved in the learning process, which needs to be open to novelties and changes, which is not necessarily the case in the Slovene study environment.

In the wake of all the forthcoming global changes that make English a lingua franca and call for its command, a critical overview of the existing coursebooks is not only well-grounded but also necessary. The analysis conducted of the three coursebooks shows that they follow a communicative approach to foreign language learning, therefore successfully develop communication skills, and are based upon a 'linguistic loop.' However, it needs to be addressed that coursebook materials are oversimplified, which makes their authenticity questionable. As such they are cognitively unstimulating and do not pose any cognitive challenges to more advanced students. Quantitative data underlies the very same conclusion. Nonetheless, it should be stressed that the materials can function as a good foundation for interdisciplinary team teaching on the condition that new materials be prepared.

Teachers and students stress that well-prepared problem-based lessons, which can be successfully realized through CLIL, are crucial in developing critical thinkers as well as for students' further professional careers. Additional value of these lessons would be more knowledge; work with authentic materials; contemporary, debatable topics; acquisition of problem-solving techniques and strategies. When and if introducing such lessons teachers also need to pay special attention to weaker students, to whom English already is a hurdle and would require an individual approach if teachers are to real- 
ize the same objectives. Yet, it should not go unnoticed that all participating teachers fear extra workload and organizational obstacles.

All in all, as the research has managed to prove benefits arising from CLIL lessons, CLIL materials and interdisciplinary team-teaching, we should strive for slow but steady implementation of this novel approach into Slovene upper-secondary education.

\section{References}

Banegas, Dario Luis. 2013. 'An Investigation into CLIL-Related Sections of EFL Coursebooks: Issues of CLIL Inclusion in the Publishing Market.' International Journal of Bilingual Education and Bilingualism 17 (3): 345-59.

Balek, Slavica, and Saša Jazbec. 2010. Pot v večjezičnost - zgodnje učenje tujih jezikov v 1. VIO osnovne šole. Ljubljana: Zavod Republike Slovenije za šolstvo.

Brumen, Mihaela, Polonca Kolbl Ivanjšič, and Mateja Pšunder. 2015. 'Pedagoški predmeti poučevanja nejezikovnih predmetov v tujem jeziku'. Revija za elementarno izobraževanje 8 (1-2): 27-42.

Coyle, Do, Peter Hood, and David Marsh. 2010. CLIL Content and Language Integrated Learning. Cambridge: Cambridge University Press.

Eurydice. 2017. Key Data on Teaching Languages at School in Europe. Luxembourg: Publications Office of the European Union.

Jazbec, Saša, and Metka Lovrin. 2015. 'Koncept CLIL - novost ali stalnica pri učiteljih na OŠ v Sloveniji, študija primera.' Revija za elementarno izobraževanje 8 (1-2): 65-79.

Lah Šuster, Anamarija. 2013. 'Učenje tujih jezikov v otroštvu - stopnja osebnosthe razvitosti in razvitosti strategij $v 2$. triadi OŠ'.' Vestnikza tujejezike 5 (1-2): 95-113.

Lipavic Oštir, Alja. 2009. 'Organizacija in okoliščine izvajanja zgodnjega učenja tujih jezikov na osnovnih šolah.' Evalvacijska študija, Filozofska fakulteta Univerze v Mariboru.

Lipavic Oštir, Alja, and Saša Jazbec. 2009. 'Vzajemno delovanje različnih dejavnikov pri uvajanju CLIL-a v šolski sistem v Sloveniji.' Didactica Slovenica - Pedagoška obzorja 24 (3-4): 104-18.

Lipavic Oštir, Alja, Alenka Lipovec, and Martina Rajšp. 2015. 'CLIL - orodje za izbiro nejezikovnih vsebin.' Revija za elementarno izobraževanje 8 (1-2): 1126.

Lucietto, Sandra. 2009. 'Writing Materials for CLIL: A Lost Cause?' Folio 13 (1): 12-14.

Ministrstvo za šolstvo in šport. 2008. 'Učni načrt: angleščina; gimnazija.' http:// portal.mss.edus.si/msswww/programi2010/programi/media/pdf/ucni _nacrti/UN_ANGLESCINA_gimn.pdf 
McKinlay, Stuart, in Bob Hastings. 2013. New Success Intermediate. Harlow: Pearson Longman.

Pavlič Škerjanc, Katja. 2010. 'Smisel in sistem kulikularnih povezav.' In Medpredmetne in kurikularne povezave, edited by Zora Rutar Ilc and Katja Pavlič Škerjanc, 19-42. Ljubljana: Zavod Republike Slovenije za šolstvo.

Pevec Semec, Katica. 2015. ‘Pedagoški pristop CLIL - izziv za profesionalni razvoj učiteljev tujega jezika na zgodnji stopnji šolanja.' Revija za elementarno izobraževanje 8 (1-2): 43-63.

Retelj, Andreja. 2015. 'Razvoj leksikalnih zmožnosti pri učenju nemščine v srednji šoli: primerjava komunikacijskega pristopa in pristopa CLIL.' Šolsko polje 26 (1-2): 67-80.

Retelj, Andreja, and Karmen Pižorn. 2010. 'Povezovanje tujih jezikov z nejezikovnimi predmeti.' Vestnik za tuje jezike 2 (1-2): 135-42.

Skela, Janez. 2008. 'Vrednotenje učbenikov angleškega jezika z vidika kognitivne teorije.' In Učenje in poučevanje tujih jezikov na Slovenskem, edited by Janez Skela, 154-82. Ljubljana: Tangram.

Skela, Janez, and Urška Sešek. 2012. 'Od globalnih smernic do lokalnih kontekstov: Učenje in poučevanje tujih jezikov v Sloveniji.' Jezik in slovstvo 57 (34): 63-81.

Tomlinson, Brian, and Hitomi Masuhara, ed. 2010. Research for Materials Development in Language Learning. London: Continuum

Vilhar, Barbara, ed. 2008. Učni načrt za biologijo, gimnazija. Ljubljana: Zavod Republike Slovenije za šolstvo. 